BNL --43714

DE9 0007675

DUAL PHOTON ABSORPTIOMETRY: VALIDATION OF

MINERAL AND FAT MEASUREMENTS

Steven B. Heymsfield, ' Jack Wang,' Mary Aulet,

Joseph Kehayias, ${ }^{2}$ Sceven Lichtman, ${ }^{1}$ Yakov Kamen. ${ }^{3}$

F. Avraham Dilmanian, ${ }^{3}$ Robert Lindsay," Richard N. Pierson, Jr."

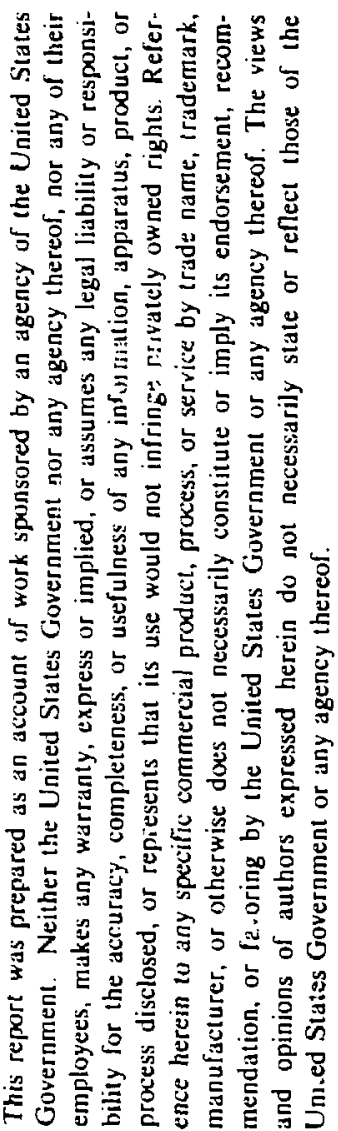

\author{
'Department of Medicine, Luke's-Roosevele and "Helen Hayes \\ Hospicals, Columbia Universicy College of Physicians and \\ Surgeons, New York; ${ }^{3}$ Brookhaven National Laboratory, Upton, \\ New York; and '2USDA Human Nutrition Research Center on \\ Aging, Boston, Massachusetts
}

\title{
INTRODUCTION
}

Photons passing through human tissue undergo attenuation in relation to the specific chemical substances with which they interact. Soft tissues, consisting largely of water and organic compounds, reduce photon flux to a lesser extent than bone mineral, which contains the intermediate $-Z$ element calcium. By selecting two appropriate photon energies and recording their attenuation, the investigator can solve simultaneous equations that subdivide body mass into two components: soft tissue and bone mineral ash (Heymsfield, et al., 1989). Systems are now available that use efther a 153 -Gadolinium ( ${ }^{153} \mathrm{Cd}$ ) source that generates photons with energies at $100 \mathrm{KeV}$ and $44 \mathrm{KeV}$ or filtered $\mathrm{X}$-rays with energies at about $70 \mathrm{KeV}$ and $40 \mathrm{KeV}$. Instruments that rely on these sources are referred to as dual photen absorprionecers (DPA) and dual energy X-ray absorptiometers (DEXA), respectively.

Dual photon systems are also capable of further resolving soft tissue into fat and fat-free components (Heymsfield er al., 1989). This is accomplished by use of the $R_{S T}$, a ratio of attenuations through soft tissue (ST) pixels at the two energy levels (Mazess et al., 1989). The $R_{\mathrm{ST}}$ is linearly and inversely correlated with the proportion of soft tissue fat. The patient's percentage fat can be calculated either by internal system calibrations or by using phantoms of known iat content. The latter approach involves serial scans of beef-lard mixtures of known composition, and then using this information to derive the subject's fat mass (Heymsfield et al, 1989; Wang et al., in press).

Fig. 1 shows the dual photon model of body composition. Body weight is divided into three components, cotal body bone ash (IBBA), fat-free : oft tissue (FFST), and fat. Total fat-free body mass (FFM) is the sum of TBBA and FEST.

The aim of this paper is to describe the joirt efforts by our group to validate the estimates of body composition derived by duai photon 
systems. Our initial studies largely involved DPA (Lunar DP4, Madison, isconsin), although cur discussion will also include the more recenty developed DEXA.

\section{MINERAL MEASLREMENTS}

The skelecon consists of mineral, protein, water, and small amounts of other compounds (Woodard, 1964). Dual photon systems estimare bone mineral ash. the skeletal fraction remaining after proloriged heating at high cemperatures (Heymsfield et al., 1989). The calcium content of bone ash in humans is reasonably constant at 34z-38\% of dry mineral weight. The primary focus in our laboratory was to validate TBBA derived by DPA against total body calcium ( $T B C a$ ), which is found almost entirely within bone mineral. An accurate and precise method of measuring TBCa. delayed gamma neutron activation analysis, is available at one of our Centers (Brookhaven National taboratory, Upton, NY). This delayed gamma system is described by Cohn ee al. (1980).

Fig. 2 presencs our study of TBBA versus TB்Ca in 31 healthy non-obese adults between the ages of 24 and 93 years ( $X \pm S D-58 \pm 20$ years) (Heymsfield et al.. 1989; Heymsfield et al.. in press). The correlation between bone ash and whole body Ca was highly significant $(T B B A=3.08 \times \mathrm{TBCa}-432, \mathrm{SEE}-238 \mathrm{~g}, r-0.94, p<0.001)$. The ratio of TBCa to TBBA was 0.380 for men, 0.377 zor women, and 0.379 for pooled subjects. These rcsults, which confirm earlier inicial findings by Mazess et al (1981), support the validity of bone mineral estimates provided by DPA.

An additional poine worthy of mention is the relation between bone ash and bone mineral. Mineral, when heated to over $500 \mathrm{C}$ and ashed, loses crystalline water and other volatile components that reduce its mass by 4-5z. We therefore use the limited data avallable to convert bone ash to osseous mineral ( $M_{0}$ ) as (Brozek et al., 1963):

$M_{0}=$ TBBA $\times 1.0 .36$

DPA MODEL

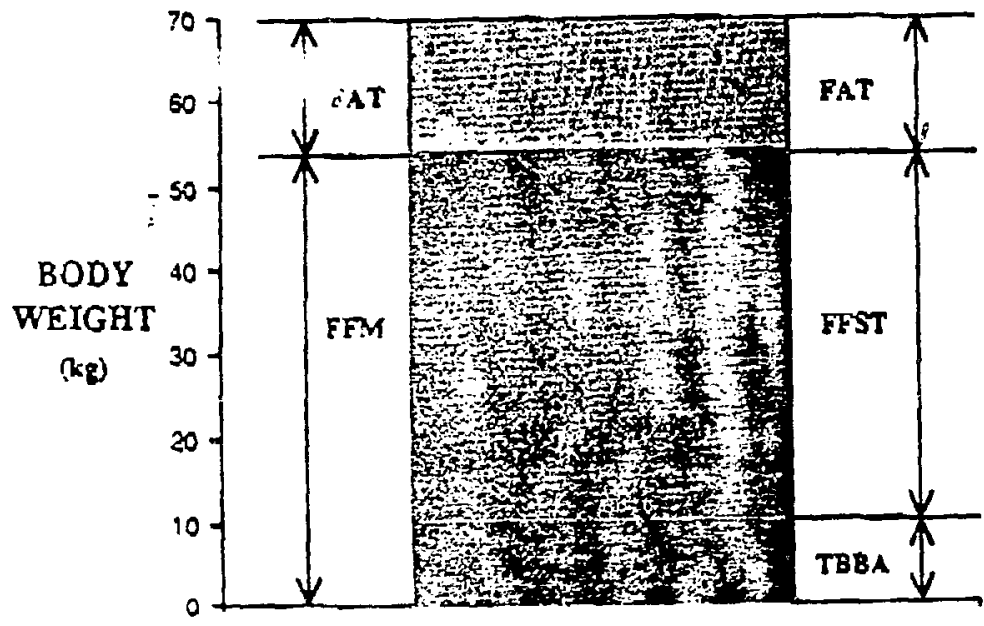

Fig. 1. Three-compartment DPA modei of body composition. F - fat, FFST - fat free soft tissue, and TBBA - total body bone ash. FFM - fac free body mass (FFST + TBBA). 
There are two reproducibllity lssues of concern in relation to bone ash measurements. Firse, each instrument should be highly zeproducible from day to day so that small changes in bone mineral over time are readily detected. The second concern relates to the rariety of instruments available that differ in technological features and mantficturer. Optimally, each instrument should provide equivalent estinaces of bone ash in the same subject. We performed two pilot studies aimed at examining each of these issues.

In the first study four subjects underwent between four and six DPA scans daily, and the TBBA results were used to calculate a coefficient of variation (CV) (Table 1 ). The range in CV's was between $0.65 \%$ and 1.697. with an average of $1.34 \mathrm{z}$ for the four subjects. We are presenty extending this study to DEXA, which reportedly has a $C V$ one-half that of DPA. For comparison, the CV for TBCa estimated by neutron activation. derived on anthropomorphic phantoms, is $0.8 \%$.

The second study involved a cross-comparison between two DPA instruments followed by a comparison of DPA to DEXA (Table 2). Eight subjects underwent DPA scan on our system (\#1, Lunar DP4) followed by a scan on a second DPA system (\$2, Norland 2600, Helen Hayes Hospital, Havestraw, NY). The mean bone mineral results differed by $2.6 \%$ and the regression line of DPA-l versus DPA-2 was almost identical to the line of idencicy (Fig. 3). The next phase involved eleven subjects who were Eirst studied using DPA-l and then underwent study using DEXA (DPX, Lunar). Again the difference in TBBA decected by the two systems was small $(X-2.7 \%)$, with a near-equivalent regression line and line of identity (Fig. 4).

Hence, these initial studies suggest that bone mineral estimates by DFA and DEXA in normal weight, healthy subjects are precise, reproducible between instruments, and compare favorably to the more complex, costly, and less accessible neutron activation method as a means of evaluating bone mineral mass in vivo.

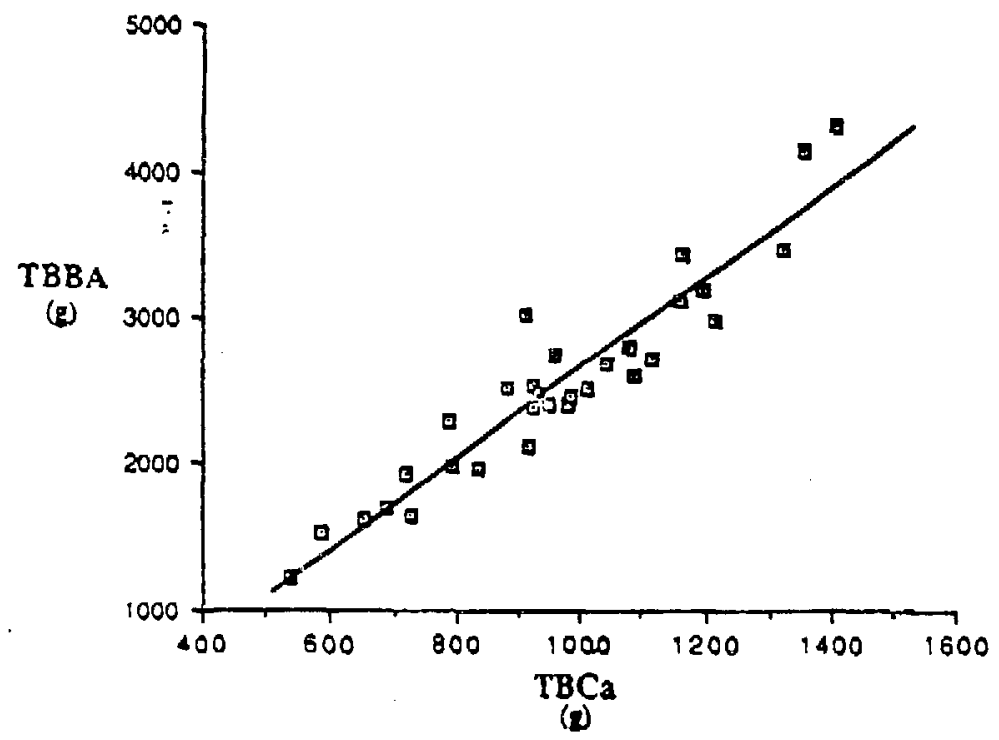

Fig. 2. TBBA on the ordinate versus total body calcium (TBCa) on the abscissa (TBBA - $3.08 \mathrm{TBCa}-432, \mathrm{SEE}-238 \mathrm{~g}, \mathrm{r}=0.94$, p<0.001) (Heymsfield et al., in press). 
Table 1 Coefficient of Variation $(x)$ in Subjects Undergoing 4.6 Daily Studies.

\begin{tabular}{|c|c|c|c|c|c|c|}
\hline \multicolumn{7}{|c|}{ Subjects } \\
\hline & 2 & 2 & 3 & 4 & 5 & $\bar{x}$ \\
\hline \multicolumn{7}{|l|}{ DPA } \\
\hline TBBA & - & 1.60 & 1.69 & 1.43 & 0.65 & 1.34 \\
\hline 7 Fat & - & 2.65 & 3.73 & 3.27 & 4.41 & $3.52(3.22)+$ \\
\hline \multicolumn{7}{|l|}{ UWW * } \\
\hline 7 Fac & - & 5.79 & 4.18 & 7.23 & - & 5.73 \\
\hline
\end{tabular}

* UWW - underwater weighing.

+ Means for 3 subjects with $\%$ fac measured using DPA and UWW.

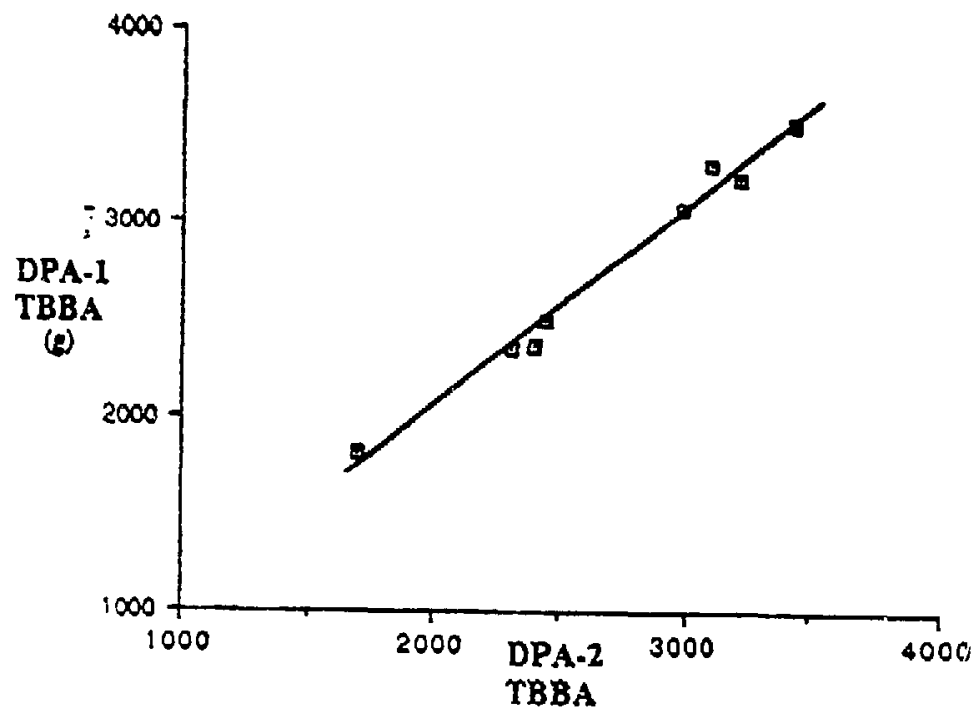

(a)

Fig. 3. TBBA measured by DPA-1 (Lunar DP4) on the ordinate versus TBBA derived by DPA-2 (Norland 2600) on the abscissa (DPA-1 - 1.02 $\mathrm{DPA}-2+18.5, \mathrm{r}=0.99, \mathrm{p}<0.001)$. 
Table 2. Comparison of Bone Ash (TBBA) Between Dual Photon Systems

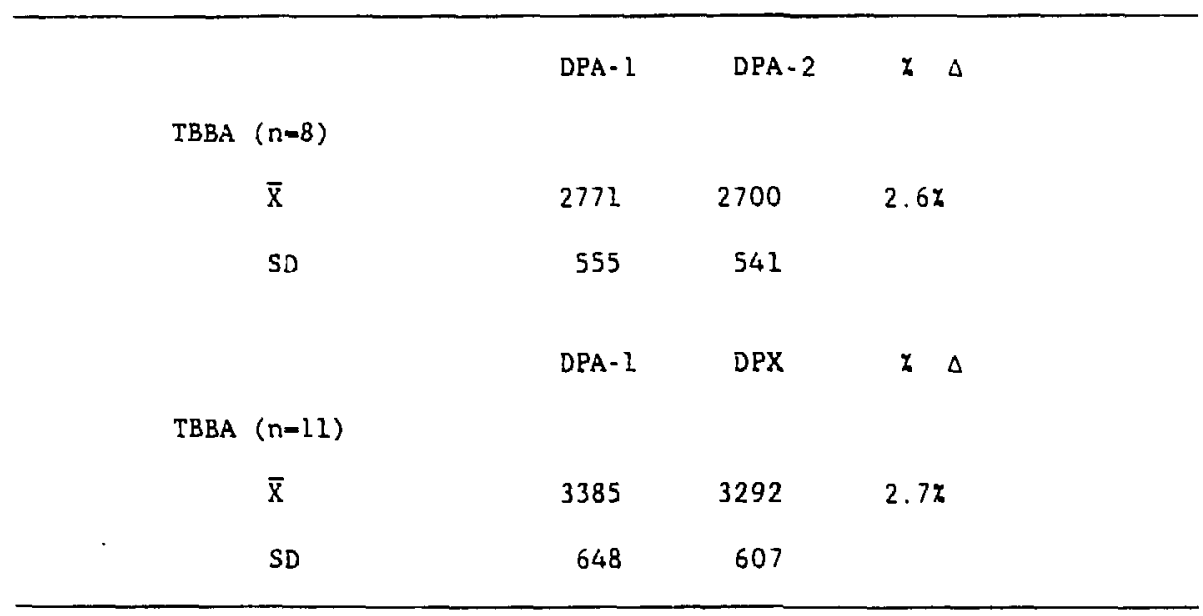

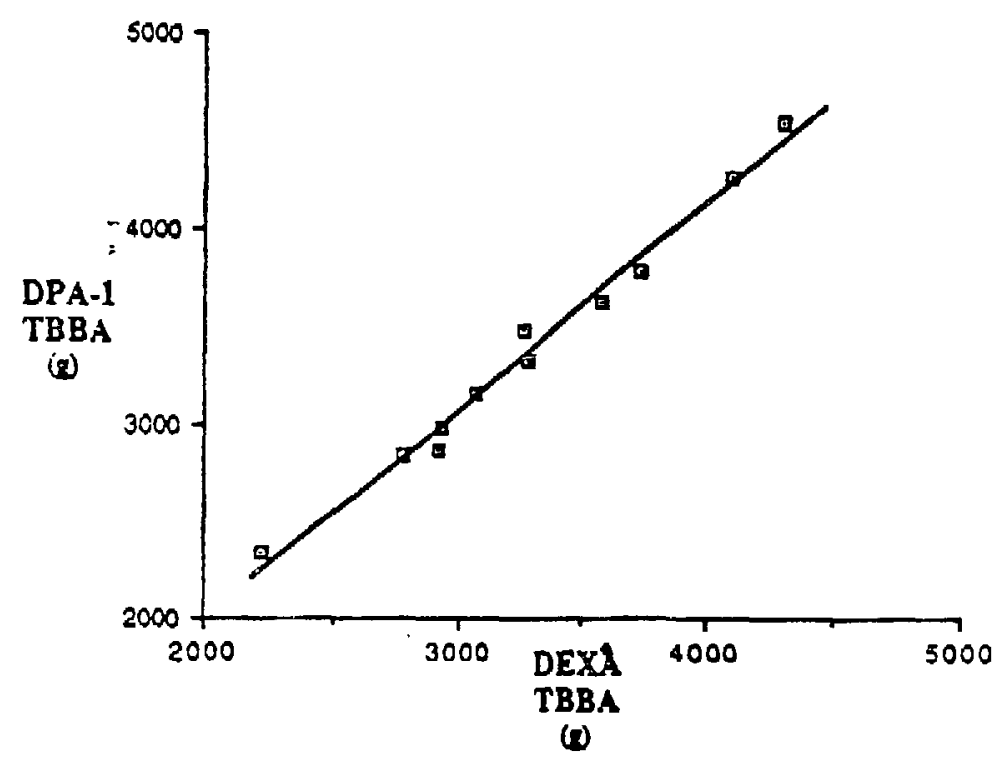

Fig. 4. TBBA measured by DPA-1 (Lunar DP4) on the ordinate versus TBBA derived by DEXA (Lunar DPX) on the abscissa (DPA-1- 1.08 DPX + 55.2, $\quad r=0.99, \quad p<0.001$ ). 
These encouraging results represent only an introductory evaluation of bone mineral escimaces by dual phocon studies. Many certr.ical and biological concerns prevail, including the effects of bod: thirkness, bone marrow fat, and ectopic calcifications on bone minerai resuiz:

\section{BODY FAT}

The studies of DPA-estimated fat at our Center involved two phases that differed in methodology and subject number. The first phase involved an excensive series of body composition measurements on the healthy non-obese subjects mentloned above (Heymsfield et al., 1989; Heymsfield et al., in press). In this analysis we compared fat derived by DPA to fat estimated from the following: total body water (TBW), hydrodensitometry (Db), and combined methodologies [Model A: TBW, TBCa, total body nitrogen (TBN), TBK, TBNa, and TBCl; and Model B: TBW, TBBA, Db] (Heymsíield et al., 1989; Heymsfield et al.. in press). In the combined methods TBW was established by tritiated water dilution; TBCa, TBNa, and TBCl by delayed gamma neutron activation (Cohn et al., 1980): TBN by prompt gamma neutron activation (Vartsky et al., 1979); and TBBA by DPA (Heymsfield et al., 1989).

Table 3 presents the results of the phase I studies. Fat estimated by DPA was on average similar to, and hijuly correlated with percentage fat derived by conventional methodologies (all $p<0.001$ ). Eig. S presents the results for DPA percentage fat versus percentage fat estimated by Model A. This multicompartment neutron activation model is unique in that measured components (TBW, TBCa, TBK, TBNa, TBCl, and TBN) are completely independent from DPA and that assumptions involved are unrelated to age, gender, and ethnicity.

In phase II we evaluated 317 healthy, non-obese Caucasians jetween the ages of 20 and 93 years. This large subject pool not only included more individuals than in phase $I$, but the age distribution was younger and more evenly balanced between males and females (Table 4). The protocol in this study was similar to phase I described above, with the exception that neution activation was not included. As in the earlier phase I, resules showed good agreement between DPA percentage fac and fat derived by conventional methodologies. Fig. 6 presents the correlation between DPA $X$ fat and $z$ fat calculated from our multicompartment model $B$, whlch is based on TBH, body density, and TBBA $(r-0.88, p<0.001)$. This model has theoretical advantages over the other two-compartment models presented in the Table (4), which fail to adjust fat estimates based on individual differences in hydration and bone mineral.

These studies Indicate that DPA is capable of partitioning soft tissues into fat and fat-free components in a manner similar to that provided by conventional methodology.

As with bone mineral measurements, there exists a concern with fat estimated by DPA in the same individual over time and between different absorptiometers. Repeated scans over time of our meat phantoms shows good reproducibiiity. For example, phantoms \#3 and \#4 on daily DPA scans have a soft tissue attenuation ratio $\left(R_{S T}\right) C V$ of $0.35 \%$ and $0.30 \%$, respectively. These CVs translate to $-2 z$ on the fat scale for $R_{\mathrm{ST}}$, which ranges between about 1.2 and 1.4 for $100 \%$ and $0 \%$ fac. When these two meat phantoms were repeatedly studjed on the newer DEXA (DPX), their $R_{S T}$ CVS decreased by about SOz to $0.16 \%$ and $0.17 \%$, respectively.

Repeated between-day studies for $y$ fat are also available for DPA on the previously mentioned four subjects (Table 1). A parallel comparison of the $C V$ for $t$ fat was made using underwater weighing in 
Table 3. Results of Phase I Scudies $(X+S D)$

\begin{tabular}{|c|c|c|c|c|c|}
\hline & $\begin{array}{c}\text { Males } \\
(n=28)\end{array}$ & $\begin{array}{l}\text { Females } \\
(n-13)\end{array}$ & $\begin{array}{l}\text { Total } \\
(n-32)\end{array}$ & $r(p) \star \star$ & SEE $(\mathrm{kg})$ \\
\hline Age & $\begin{array}{l}55.2 \\
\pm 18.8\end{array}$ & $\begin{array}{r}62.5 \\
+22.5\end{array}$ & $\begin{array}{r}58.3 \\
\pm 20.4\end{array}$ & - & - \\
\hline$B M I$ & $\begin{array}{r}23.9 \\
\pm 2.2\end{array}$ & $\begin{array}{l}22.8 \\
\pm 3.1\end{array}$ & $\begin{array}{l}23.4 \\
\pm 2.6\end{array}$ & - & . \\
\hline \multicolumn{6}{|l|}{$\geq$ Eat * } \\
\hline DPA & $\begin{array}{l}20.8 \\
\pm 5.1\end{array}$ & $\begin{array}{r}32.3 \\
\pm 7.3\end{array}$ & $\begin{array}{l}25.6 \\
\pm 8.3\end{array}$ & - & - \\
\hline TBW & $\begin{array}{r}18.9 \\
\pm 7.3\end{array}$ & $\begin{array}{l}28.6 \\
\pm 7.9\end{array}$ & $\begin{array}{r}23.0 \\
\pm 8.9\end{array}$ & $\begin{array}{c}0.91 \\
(0.001)\end{array}$ & 3.6 \\
\hline UWW & $\begin{array}{r}21.6 \\
\pm 5.8\end{array}$ & $\begin{array}{r}31.0 \\
\pm 8.9\end{array}$ & $\begin{array}{r}25.6 \\
\pm 8.5\end{array}$ & $\begin{array}{c}0.88 \\
(0.001)\end{array}$ & 4.0 \\
\hline hodel $A$ & $\begin{array}{l}24.1 \\
\pm 7.3\end{array}$ & $\begin{array}{r}33.0 \\
\pm 9.3\end{array}$ & $\begin{array}{r}27.9 \\
\pm 9.2\end{array}$ & $\begin{array}{c}0.90 \\
(0.001)\end{array}$ & 3.8 \\
\hline Model B & $\begin{array}{l}22.6 \\
\pm 6.2\end{array}$ & $\begin{array}{r}32.0 \\
\pm 8.3\end{array}$ & $\begin{array}{l}26.5 \\
\pm 8.5\end{array}$ & $\begin{array}{c}0.93 \\
(0.001)\end{array}$ & 3.2 \\
\hline
\end{tabular}

* z fat by DPA, 3 H2O dilution (TBW), underwater weighing (UWW), Model A - comblned TBW, TBN, TBCa, TBK, TBNa, and $T B C l$, and Model $B$ - combined TBW, UWW, and DPA TBBA.

* DPA $z$ fat versus corresponding $x$ fat.

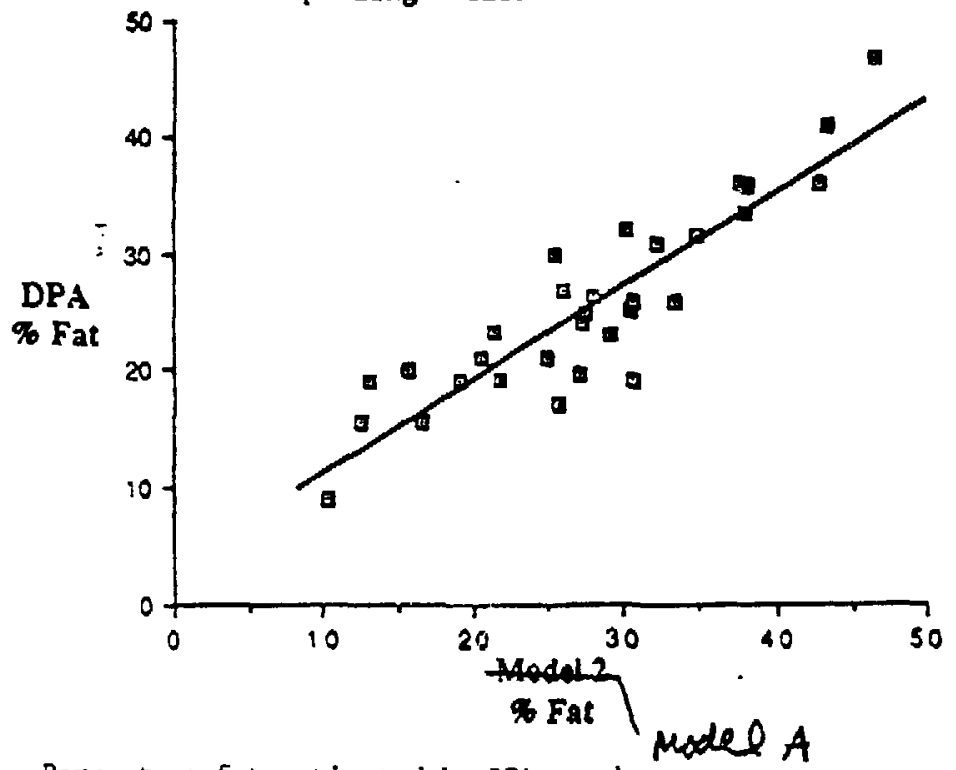

Fig. 5. Percentage fat estinated by DPA on the ordinate versus percentage fat derived by mulcicompartment neutron activation model on the absclisa [DPA Fat $(x)=0.81$

Model A Eat +3.1, SEE -3.87, r $-0.90, p<0.001]$ 
Table 4. Resulzs of Phase Ii Scudies ( $X_{ \pm} S D$ )

\begin{tabular}{|c|c|c|c|c|c|}
\hline & $\begin{array}{c}\text { Males } \\
\left(r_{t}=i i 1\right)\end{array}$ & $\begin{array}{l}\text { Eemales } \\
(n-206)\end{array}$ & $\begin{array}{c}\text { Total } \\
(n=317)\end{array}$ & $r(p) * *$ & $S E E(\mathrm{~kg})$ \\
\hline Age & $\begin{array}{r}53.7 \\
\pm 17.1\end{array}$ & $\begin{array}{r}52.7 \\
\pm 18.5\end{array}$ & $\begin{array}{r}53.1 \\
\pm 18.0\end{array}$ & - & - \\
\hline BHI & $\begin{array}{l}24.8 \\
\pm 2.7\end{array}$ & $\begin{array}{l}22.7 \\
\pm 2.8\end{array}$ & $\begin{array}{r}23.5 \\
\pm 3.0\end{array}$ & - & - \\
\hline \multicolumn{6}{|l|}{$\underline{\text { fat }}$ * } \\
\hline DPA & $\begin{array}{r}20.9 \\
\pm 5.9\end{array}$ & $\begin{array}{l}30.9 \\
\pm 8.0\end{array}$ & $\begin{array}{l}27.4 \\
\pm 8.9\end{array}$ & - & - \\
\hline $\mathrm{TBW}$ & $\begin{array}{l}21.1 \\
\pm 8.4\end{array}$ & $\begin{array}{l}29.4 \\
\pm 7.8\end{array}$ & $\begin{array}{l}26.5 \\
\pm 9.0\end{array}$ & $\begin{array}{l}0.79 \\
(0.001)\end{array}$ & 5.4 \\
\hline UWW & $\begin{array}{l}22.7 \\
\pm 6.1\end{array}$ & $\begin{array}{l}29.1 \\
\pm 7.8\end{array}$ & $\begin{array}{l}26.9 \\
\pm 9.0\end{array}$ & $\begin{array}{c}0.81 \\
(0.001)\end{array}$ & 3.2 \\
\hline Yodel B & $\begin{array}{l}22.0 \\
\pm 6.7\end{array}$ & $\begin{array}{l}29.6 \\
\pm 7.3\end{array}$ & $\begin{array}{l}27.0 \\
\pm 8.0\end{array}$ & $\begin{array}{c}0.88 \\
(0.001)\end{array}$ & 1.4 \\
\hline
\end{tabular}

* $\boldsymbol{z}$ fat by DPA. $3 \mathrm{H} 20$ dilution (TBW), underwater weighing (UWW), and Model B - combined TBW, UWW, and DPA TBBA.

** DPA $x$ fat versus corresponding $x$ fac.

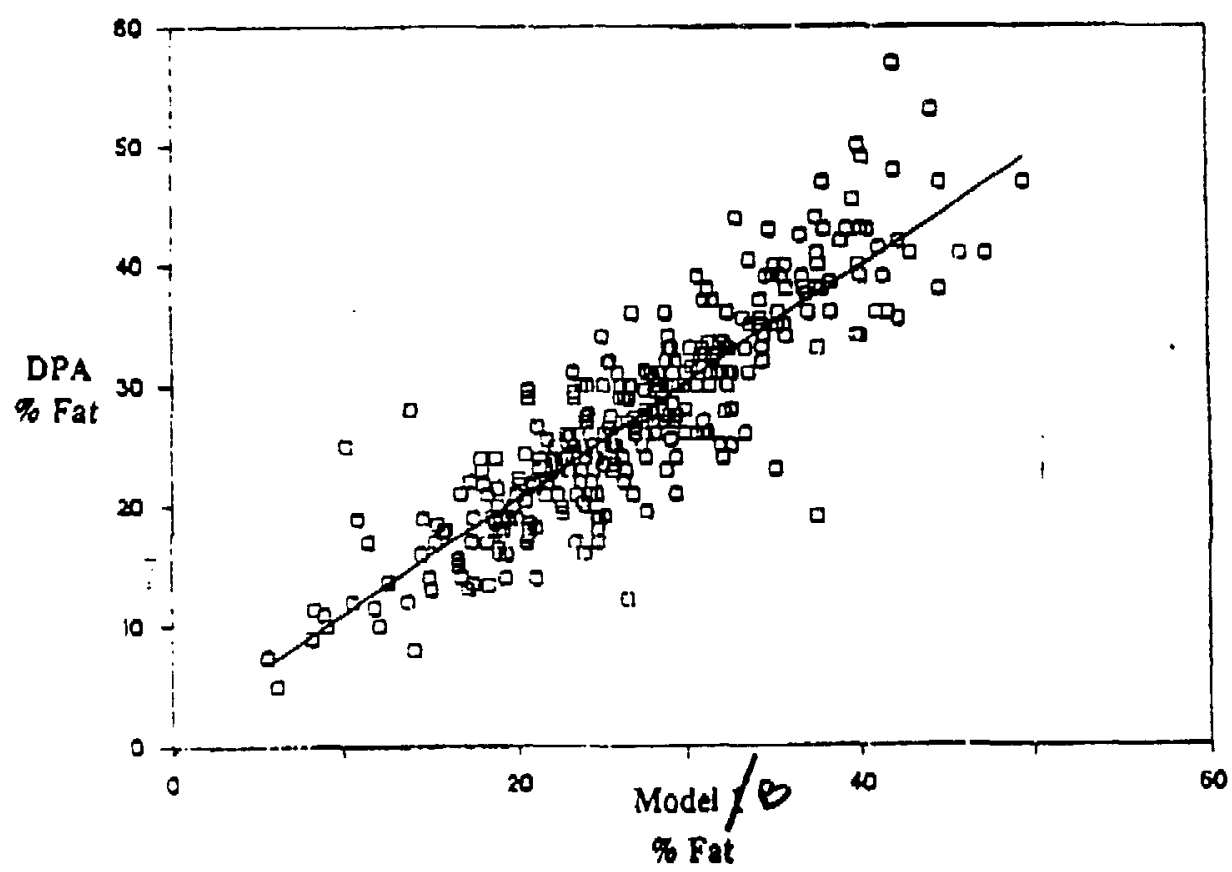

Fig. 6. Percentage fat estinated by DPA on the ordinate versus percentage fat derived by multicompartment model $B$ on tise abscissa [DPA Fat $(\boldsymbol{y})=0.91$ model B Fat $+1.5, \operatorname{SEE}=3.2 \%$, $r=0.93, p<0.001]$. 
three of these individuals. The mean CVs for $z$ fat by DPA and underwater weighing were $3.22 x$ and $5.73 \%$, respectively for the three subjects undergoing both studies. The mean $\chi$ fat in this group was 28.27 by DPA, so the CV represents about $1 x$ total body fat. We anticipate improved precision with the newly introduced DEXA.

The question of between-instrument comparability is an important one that as yet does not have a definitive answer. Our initial studies can be briefly summarized, and they indicate that discrepancies exist between fat estimated by meat phantoms and by internal instrument calibrations, between different instruments, and between DPA and DEXA. These observed differences are worthy of further analysis, and extensive comparative studies are now underway at our Center.

As with bone mineral estimates, future studies need to examine the effects of body size and other condicions, such as state of hydration, on percent fat estimates by DPA.

\section{APPENDICULAR SKELETAL MUSCLE}

The fat-free, non-osseous portion of the extremities is almost entirely skeletal muscle, with skin and bone marrow comprising less than 5 percent of soft lean appendicular mass (Heymsfield et al., in press). As DPA software can isolate the extremities, this affords the opportunity to quantify a large portion $(70-75 x)$ of skeletal muscle mass in vivo. Our approach was to first develop a simple model of extremity composition. Limb bone ash was converted to skeletal weight by assuming ash comprises $55 \%$ of defatted fresh bone mass (Heymsfleld et al., in press). Extremity fat was estimated by the beef phantom calibration procedure described earlier (Heymsfield et al., 1989). Appendicular skeletal muscle was then calculated as total limb mass minus fat and bone mass.

The validity of the DPA method for appendicular skeletal muscle mass was evaluated on subjects of the phase I and three additional healthy, lean individuals $(n-34)$ by comparing DPA results to TBK, TBN, and muscle calculated from anthropometric estimates and combined methodologies (Heymsfield et al., in press). The calculated muscle estimates involves use of two models of skeletal muscle mass proposed by Burkinshaw (1985, Burkinshaw et al., 1987). One model requires measurement of TBK and TBN, and the second model is based on TBK and fat-free body mass. Our approach to the second model was to calculate fat-free body mass as body weight minus. DPA fat.

Total (upper and lower) DPA appendicular skeletal muscle mass was highly correlated with IBK ( $r-0.94, p<0.001 ;$ Fig. 7) and summed upper plus lower anthropometric limb muscle plus bone cross sectional areas $(r=0.92, p<0.001)$. Significant, but weaker correlations were observed between DPA limb muscle and TBN $(r-0.78, p<0.001)$, and between DPA Iimb muscle and estimates of whole body skeletal muscle mass based on Burkinshaw's tro models (both $r=0.82$, $p<0.001$ ). These initial results are encouraging and suggest that DPA may also be useful as a means of quantifying a large proportion of skeletal muscle mass in vivo.

\section{APPLICATIONS AND CONCLUSION}

The avallability of total body bone mineral measurements outside the few neutron activation centers that can quantify TBCa is an important advance in the field of body composition. The traditional two-compartment model of fat and fat-free body mass can be expanded to 
further subdivide lean tissues into FFST and TBBA. Moreover, by mbining DPA with other methods, such as ${ }^{3} \mathrm{H}_{2} \mathrm{O}$ dilution, the investigacor could potentially evaluace four $\left(\mathrm{H}_{2} \mathrm{O}\right.$, mineral, protein, Eat) or more body compartments. The door is thus open to answering countless interesting and important questions in human biology previously limited by our inability to quantify skeletal mineral mass.

Similarly, the ability to quantify appendicular skeletal muscle mass, given the limitacions of other available muscle- measuring rechniques, is a novel and important feature of dual photon systems. The combined capacity to estimate skelecal muscle and bone mineral simultaneously in the appendages further expands the range of questions answerable by these methodologies.

Finally, although fat can be measured using other techniques, dual photon systems offer a new approach independent from classical assumptions or models related to body composition.

\section{ACKNOWLEDGEMENTS}

Supported in part by NIH grants AR 39191, DK 41000 and DK 37352, and U.S. DOE contrace DE-ACO2-76CH00016.

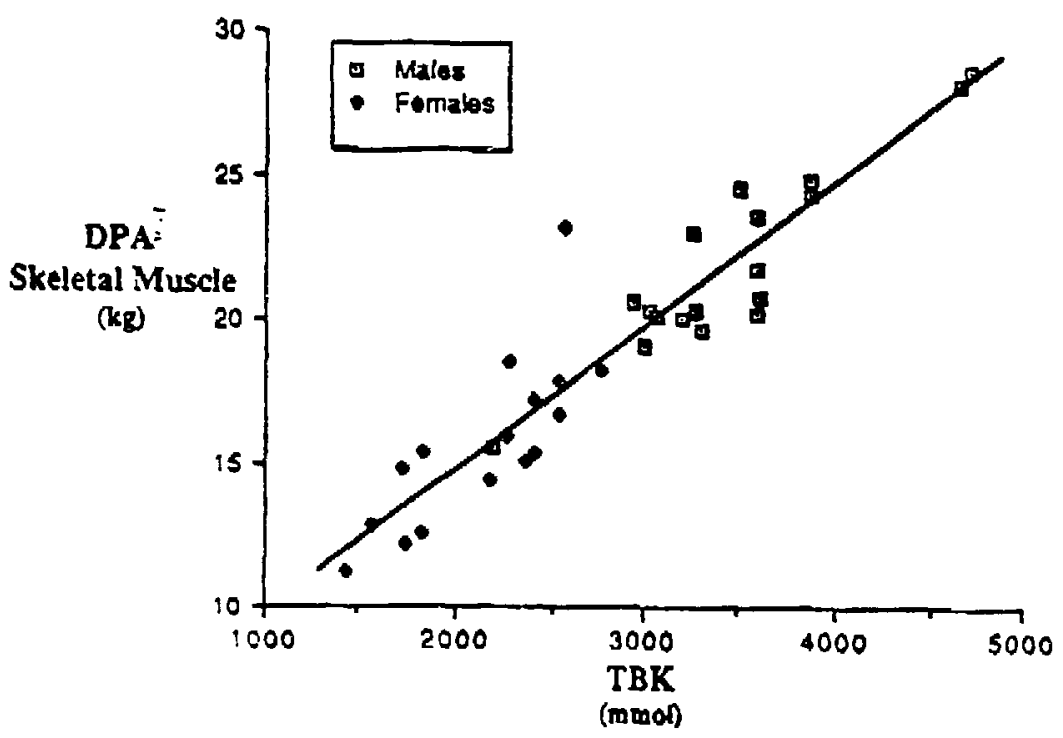

Fig. 7. DPA total appendicular skeletal muscle mass on the ordinate versus TBK on the abseissa (DPA muscle ( $\mathrm{g}$ ) - 0.0005 $\times$ TBK + $5.0, S E E=1.6 \mathrm{~kg}, \mathrm{r}=0.94, \mathrm{p}<0.001$ ) (Heymsfield et al., in press). 


\section{REFERENCES}

Brozek, J., Grande, F゙., Anderson, T, Keys, A., 1963, Densitometric analysis of body composition: revision of some assumptions, tnn. N.Y. Acad. Sci., 110:113-140.

Burkinshaw, L., 1985, Measurement of human body composition in vivo, in: "Progress in Medical Radiation Physics," Vol: 2, C. G. Orton, ed. Plenum Publishing Corporation, New York.

Burkinshaw, L.. 1987, Models of the distribution of protein in the human body, in: "In Vivo Body Composition Studies," K. J. Ellis, S. Yasumura, and W. D. Morgan, eds.. Institute of Physical Sciences in Medicine, London.

Cohn, S.H., Vartsky, D., Yasumura, S., Sawitsky, A., Zanzi, I., Vaswani, A., Ellis, K.J., 1980, Sompartmental body composition based on tocal body nitrogen, potassium, and calcium, Am. J. Physiol, $239:$ ES24.

Heymsfield, S.B., Lichtman, S., Baumgarener, R.N., Wang, J., Kamen, Y., Aliprantis, A., Pierson, R,N., Human body composition: comparison

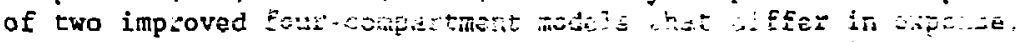
cechnical complexity, and radiation exposure, Am $\mathrm{J} C \mathrm{Cl}$ in Nutr, in press.

Heymsfield, S.B., Smith, R., Aulet, M., Bensen, B., Lichtman, S. Wang. J., Pierson R.N.. Appendicular skelecal muscle mass: measlirement by dual photon absorpeiometry, Am $J \mathrm{Cl}$ in Nutr, in press.

Heymsfield, S.B., Wang, J., Kehayias, J., Heshka, S., Lichrman, S., Pierson, R.N., Chemical determination $c_{i}$ human body density in vivo: relevance to hydrodensitometry, Amer $J$ Clin Nutr, 50: $1282-1289,1989$.

Heymsfield, S.B., Wang, J., Kehayias, J.J., Pierson, R.N., 1989, Dual photon absorptiometry: comparison of bone mineral and soft tissue mass messurements in vivo with established methods, Am. J. Clin. Nutr., 49:1283.

Mazess, R.B. Peppler, W.H, Chestnut, C.H, 1981, Total body bone mineral and lean body mass by dual photon absorpelometry. II. Comparison with tocal body calcium by neutron activation analysis, Calcif. Tiss, Int.. 33:361.

Mazess, R.N., Peppler, W.W., Gibbons M., 1984, Total body composition by dual-photon (153Gd) absorptiometry, Am. J,Clin. Nutr, 40:834.

Varesky, D., Ellis, K.J., Cohn, S.H., 1979, In vivo quantification of body nitrogen by neutron capture prompe gamma-ray analysis, I Nucl Med 20:1158.

Wang. J., Heymsfield, S.B., Aulet, M.. Thornton, J.C., Pierson, R.N., 1989, Body fat from body density: underwater weighing vs dual pheton absorptiometry, Am. J. Physiol, in press.

Woodard, H.Q., 1964. The composition of human corticol bone, Clin. Orthop., $37: 187$ 